\title{
Bond Ratings dan Antesedennya: Studi Empiris di Bursa Efek Indonesia
}

\author{
Wendy* \\ Universitas Tanjungpura \\ Rosita Naomi Sianturi \\ Universitas Tanjungpura
}

\begin{abstract}
This paper provides the empirical evidence of corporate growth, maturity, and operating cash flows on the bond ratings. It was conducted on 34 bonds issued by the 16 non-financial companies on the Indonesia Stock Exchange (IDX) which also issued bonds, registered in the Indonesia Bond Market Directory, and rated by PEFINDO during 2012 - 2014. The hypotheses were tested using the logistic regression analysis. The result shows that corporate growth has significant effect on the bond ratings, while maturity and operating cash flow have no significant effect. Another finding shows that the firm size can also affect the bond ratings.
\end{abstract}

Keywords: corporate growth, maturity, operating cash flow, firm size, bond ratings.

\section{PENDAHULUAN}

Obligasi merupakan salah satu instrumen investasi jangka menengah dan panjang yang diperdagangkan di Bursa Efek Indonesia (BEI). Instrumen ini memberi penghasilan yang bersifat tetap kepada para pemegangnya hingga umur obligasi (maturitas atau jatuh tempo) berakhir (Bodie, Kane \& Marcus, 2008). Instrumen ini sering digunakan sebagai salah satu alternatif dalam mencari sumber pendanaan eksternal (financing) yang dapat digunakan baik oleh Pemerintah maupun Swasta (Hartono, 2016). Penerbit obligasi diposisikan sebagai pemilik hutang, sementara pembeli obligasi sebagai pihak yang memberi pinjaman (Darmadji \& Hendy, 2006). Penerbitan obligasi diatur dalam mekanisme Pasar Modal Indonesia (Bursa Efek Indonesia-BEI), di mana salah satunya wajib dilakukan pemeringkatan (rating) terlebih dahulu untuk menganalisis tingkat kesehatan penerbit obligasi.

Isu peringkat obligasi (bond ratings) menjadi penting karena investor akan membandingkan tingkat kupon (bunga obligasi) yang diberikan dengan tingkat risiko gagal bayar (default risk) perusahaan penerbit. Hubungan terbalik antara tingkat kupon dengan peringkat obligasi beserta anteseden-antesedennya menjadi poin penting yang

\footnotetext{
* Korespondensi: Wendy, Jurusan Manajemen, Fakultas Ekonomi dan Bisnis, Universitas Tanjungpura, Jalan Prof. DR. H. Hadari Nawawi, Pontianak 78124, Indonesia. Email: wendy.gouw@gmail.com
} 
perlu diperhatikan dalam kajian obligasi. Riset ini ditujukan untuk menganalisis sekelumit permasalahan tersebut, terutama yang berpotensi memengaruhi peringkat obligasi.

Sebagaimana dijelaskan di awal bahwa salah satu risiko terbesar dalam investasi obligasi adalah risiko gagal bayar, yang berpotensi menyebabkan tidak kembalinya nilai investasi akibat financial distress (kesulitan keuangan) yang dihadapi penerbit, maka analisis bond ratings menjadi penting. Investor akan berusaha mencari informasi mengenai perubahan rating tersebut sebagai ukuran tingkat kesehatan perusahaan penerbit. Dengan demikian, penerbit perlu memperhatikan anteseden apa saja yang dapat memengaruhi bond ratings sehingga dapat mengoptimalkan diri ketika berencana menerbitkan obligasi. Rating yang tinggi juga berdampak pada lebih rendahnya tingkat kupon yang ditawarkan, sehingga cost of capital perusahaan dapat ditekan. Tingginya rating menyebabkan perusahaan dapat menikmati sumber pembiayaan yang lebih berkualitas dengan biaya bunga (kupon) yang relatif rendah.

Pemeringkatan yang dilakukan oleh lembaga independen di Indonesia (PT Pefindo) bertujuan untuk menilai perusahaan dari berbagai faktor (secara langsung maupun tidak langsung), khususnya yang berhubungan dengan kesehatan keuangan perusahaan. Hasil pemeringkatan mencerminkan kemampuan perusahaan penerbit obligasi untuk memenuhi kewajiban finansialnya (Estiyanti \& Gerianta, 2014). Selain itu, melalui pemeringkatan obligasi, BEI juga memberi perlindungan kepada pemegang obligasi dengan menyajikan informasi potensi default risk secara periodik sehingga investor dapat mengukur potensi risiko yang dihadapi dalam setiap jenis obligasi.

Riset ini berfokus pada analisis anteseden-anteseden bond ratings, seperti tingkat pertumbuhan perusahaan (corporate growth), umur maturitas (maturity), arus kas operasi (operating cash flow), dan ukuran perusahaan (size). Dengan menggunakan regresi Logistik, hasil kajian secara umum menunjukkan adanya pengaruh empiris antara pertumbuhan dan ukuran perusahaan dengan peringkat obligasi.

Tulisan ini diorganisir menjadi lima bagian. Bagian pertama menjelaskan isu dan latar belakang yang dibahas dalam Pendahuluan. Bagian selanjutnya (Kajian Literatur) menyintesis berbagai kajian literatur yang relevan, yang selanjutnya diikuti dengan penjelasan Metoda Penelitian pada bagian ketiga. Bagian keempat menjelaskan Hasil Penelitian, sementara bagian terakhir tulisan ini mendiskusikan beberapa simpulan, rekomendasi, keterbatasan riset, dan isu-isu untuk penelitian bond ratings selanjutnya.

\section{KAJIAN LITERATUR}

Obligasi (bond) adalah surat berharga yang menunjukkan bahwa penerbit obligasi meminjam sejumlah dana kepada masyarakat dan berkewajiban untuk membayar bunga secara berkala serta kewajiban melunasi pokok utang pada waktu yang telah ditentukan kepada pihak pembeli obligasi tersebut (Hartono, 2016; Mahfudho, 2014; Murhadi, 2013; Rahardjo, 2004; Safitri, 2014; Sartono, 2012). Peringkat obligasi dikeluarkan oleh 
lembaga yang secara khusus bertugas memberikan peringkat atas semua obligasi yang diterbitkan perusahaan.

Tujuan utama proses rating adalah memberikan informasi akurat mengenai kinerja keuangan, posisi bisnis industri perseroan yang menerbitkan surat utang (obligasi) dalam bentuk peringkat kepada calon investor (Surya, 2015; Susanto, 2015). PT Pemeringkat Efek Indonesia (PEFINDO) melakukan penilaian pemeringkatan atas efek utang berdasar kemampuan pelunasan pembayaran, struktur yang diatur dalam penerbitan obligasi tersebut dan perlindungan atas klaim investor apabila terjadi default (likuidasi). Peringkat obligasi tersebut dilihat berdasar nilai pemeringkatan yang dilakukan oleh PEFINDO, yang dapat dibagi menjadi dua kategori, yaitu investment grade (AAA, AA, A, BBB) dan non-investment grade (BB, B, CCC, D).

Pengukuran variabel dependen peringkat obligasi dilakukan dengan menglasifikasi peringkat obligasi ke dalam kategori masing-masing peringkat tersebut, yaitu angka 1 untuk high investment (AAA dan AA,) dan angka 0 untuk low investment (A, BBB, BB, B, CCC, dan D). Hasil penghitungan klasifikasi disajikan pada Tabel 1.

\section{Tabel 1. Klasifikasi Peringkat Obligasi di BEI}

\begin{tabular}{lccc}
\hline $\begin{array}{c}\text { Simbol } \\
\text { Peringkat }\end{array}$ & $\begin{array}{c}\text { Jumlah } \\
\text { Simbol }\end{array}$ & $\begin{array}{c}\text { Proyeksi } \\
\text { Angka }\end{array}$ & $\begin{array}{c}\text { Total Simbol (X) } \\
\text { Proyeksi Angka }\end{array}$ \\
\hline idAAA & 12 & 8 & 96 \\
idAA & 58 & 7 & 406 \\
idA & 30 & 6 & 180 \\
idBBB & 2 & 5 & 10 \\
idBB & 0 & 4 & 0 \\
idB & 0 & 3 & 0 \\
idCCC & 0 & 2 & 0 \\
idD & 0 & 1 & 0 \\
\hline \multicolumn{1}{c}{ Total } & $\mathbf{1 0 2}$ & & $\mathbf{6 9 2}$ \\
& & Rerata & $\mathbf{6 . 7 8}$ \\
\hline
\end{tabular}

Tabel satu membagi seluruh obligasi yang diobservasi dalam riset ini (tersaji dalam Tabel 2) ke dalam dua kelompok, yaitu peringkat high-investment (di atas nilai rerata) dan low investment (di bawah nilai rerata). Tabel ini disajikan untuk memberi gambaran secara matematis mengenai proses penglasifikasi peringkat obligasi berdasar High Investment dan Low Investment menggunakan rerata yang dihitung dari jumlah simbol peringkat masing-masing dikalikan dengan proyeksi angka, yang diurutkan berdasar peringkat terendah (idD) dengan angka 0 sampai peringkat tertinggi (idAAA) dengan angka 8. Nilai tengah ini (6.78) selanjutnya digunakan sebagai cut of point untuk menentukan obligasi yang tergolong sebagai low investment (di bawah 6.78) dan high investment (di atas 6.78).

Penelitian ini menganalisis beberapa anteseden bond ratings (pertumbuhan, maturitas, arus kas operasi, dan ukuran perusahaan). Pertumbuhan perusahaan merupakan salah satu tahap dalam siklus hidup perusahaan. Model siklus hidup perusahaan yang diperkenalkan oleh Antony dan Ramesh (1992) serta Restuti (2007) dikelompokan menjadi tiga tahap yaitu growth, mature, dan stagnant. Pada tahap growth, perusahan telah 
memeroleh tahap awal kesuksesan produknya di pasar. Perusahaan terus memperluas pasar produknya serta meningkatkan inovasi pada lini produksinya sehingga membutuhkan pembiayaan yang besar. Pada tahap mature umumnya volume penjualan sudah stabil, dan tingkat inovasi mulai menurun. Selain itu, perusahaan sudah berukuran besar dan berfungsi secara efesien. Perusahaan pada tahap ini sudah memasuki tahap pertumbuhan yang melambat.

Tahap selanjutnya yaitu stagnant. Pada tahap ini, kondisi perusahaan yang menurun akan diikuti oleh penurunan profitabilitas karena hilangnya pangsa pasar dan kurangnya inovasi. Pertumbuhan merupakan kemampuan suatu perusahaan untuk meningkatkan ukuran perusahaan tersebut yang dilihat dari kondisi finansialnya (Sirma Nila Sucipta \& Rahyuda, 2015). Pertumbuhan perusahaan dalam penelitian ini diukur dengan total aktiva. Restuti (2007) menyimpulkan bahwa pertumbuhan perusahaan memiliki pengaruh negatif terhadap rating obligasi.

Maturitas atau jatuh tempo merupakan tanggal di mana pemegang obligasi akan mendapatkan pembayaran kembali pokok atau nilai nominal obligasi yang diinvestasikannya. Menurut Wijayanti (2014) ada pengaruh yang signifikan antara maturitas dengan peringkat obligasi. Aliran kas operasi adalah arus kas yang berasal dari aktivitas operasional perusahaan. Penelitian yang dilakukan Octavia (2014) menunjukan tidak adanya pengaruh aliran kas operasi terhadap peringkat obligasi.

Ukuran perusahaan (size) menunjukan besar kecilnya perusahaan yang dapat diukur dengan total aktiva (Ln TA) maupun nilai kapitalisasi pasar (Febriani, Nugraha \& Saryadi, 2013; Yuniati, 2012). Penelitian ini menggunakan ukuran perusahaan dilihat dari nilai kapitalisasi pasarnya. Hasil riset Asih (2012) menunjukkan adanya pengaruh antara ukuran perusahaan dengan peringkat obligasi.

Riset ini menguji dua model penelitian, pertama dengan mengabaikan efek Ukuran Perusahaan (SIZ) dan model kedua dengan melibatkan SIZ. Kedua model tersebut disajikan pada persamaan satu dan dua.

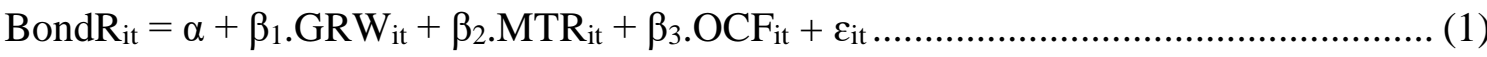

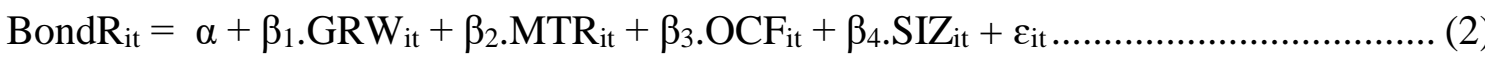

Keterangan:

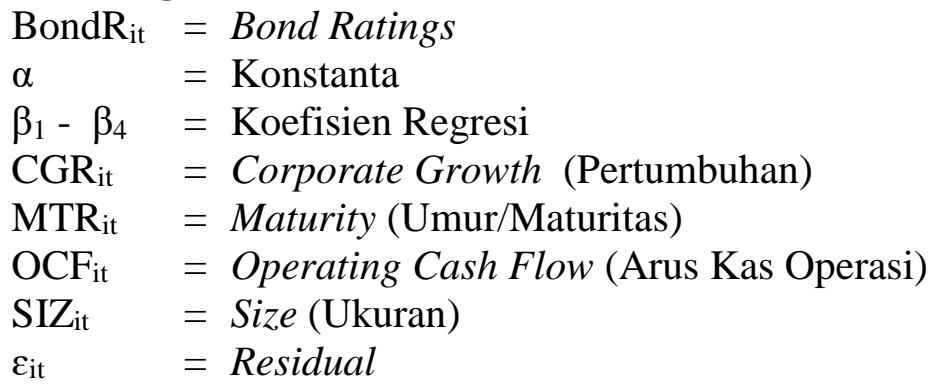


Pertumbuhan perusahaan (GRW) dapat memengaruhi perubahan rating obligasi karena perusahaan yang sedang bertumbuh mengindikasi bahwa perusahaan tersebut sedang membutuhkan banyak dana untuk investasi (Restuti, 2007). Mengacu pada model trade-off dalam teori struktur modal, perusahaan yang membutuhkan banyak dana investasi berpotensi meningkatkankan rasio hutangnya. Naiknya rasio hutang yang tidak diimbangi dengan pertumbuhan profitabilitas yang stabil cenderung akan meningkatkan risiko keuangan (tercermin dari timbulnya kesulitan keuangan (financial distress) dan potensi kebangkrutan). Apabila perusahaan yang sedang diperingkat berada pada kondisi tersebut, maka potensi untuk dinilai sebagai entitas dengan default risk tinggi dapat terjadi. Logika konseptual tersebut mendukung pengembangan hipotesis pertama.

\section{$\mathrm{H}_{1}$ : Pertumbuhan berpengaruh negatif terhadap Peringkat Obligasi}

Obligasi dengan umur atau tanggal jatuh tempo yang lebih singkat (misalnya dalam tiga tahun) cenderung lebih mudah di prediksi dibandingkan obligasi yang berumur lebih panjang dari itu (Sirma Nila Sucipta \& Rahyuda, 2015). Obligasi yang semakin mudah diprediksi umumnya memiliki risiko yang lebih kecil dibandingkan dengan obligasi dengan tingkat ketidakpastian (uncertainty) yang tinggi. Hal ini juga tercermin dari kompensasi coupon rate sebagai premi risiko yang lebih tinggi pada obligasi-obligasi dengan maturitas yang panjang (Fauziah, 2014). Dengan demikian, obligasi dengan maturitas yang lebih pendek cenderung memiliki default risk yang lebih rendah karena faktor uncertainty yang relatif rendah sehingga lebih predictable. Argumentasi tersebut mendukung pengajuan hipotesis dua.

\section{$\mathrm{H}_{2}$ : Maturitas berpengaruh positif terhadap Peringkat Obligasi}

Ross, Westerfield, Jordan, Lim \& Tan (2015) menjelaskan bahwa Arus Kas Operasi (OCF) secara tidak langsung menunjukan apakah arus kas masuk dari kegiatan operasional mampu menutupi arus kas keluar harian. Nilai OCF yang negatif mengindikasi adanya permasalahan. Informasi mengenai arus kas operasi akan membantu para pemodal dalam menilai kemampuan perusahaan menghasilkan arus kas bersih positif serta memenuhi semua kewajibannya (termasuk kemampuan membayar dividen dan bunga di masa mendatang). Indikator arus kas operasi dapat digunakan dalam pemeringkatan obligasi (Octavia, 2014). Arus kas operasi menjadi salah satu acuan bagi investor dalam memilih obligasi, karena arus kas operasi menggambarkan kemampuan perusahaan dalam menghasilkan kas dari aktivitas operasinya. Nilai OCF yang positif secara tidak langsung menunjukan kemampuan Penerbit obligasi untuk memenuhi kewajibannya sehingga potensi default risk relatif lebih rendah. Reviu tersebut mendukung pengembangan hipotesis tiga.

$\mathrm{H}_{3}$ : Arus Kas Operasi berpengaruh positif terhadap Peringkat Obligasi.

Penelitian ini juga menguji efek ukuran perusahaan (SIZ) menggunakan nilai kapitalisasi pasar. Rahardjo (2004) menggunakan kapitalisasi pasar (nilai pasar dari saham yang diterbitkan atau outstanding share) sebagai proksi ukuran perusahaan. Kapitalisasi 
pasar yang besar menunjukan prospek perusahaan yang baik dan tingkat risiko yang relatif rendah sehingga rating obligasi (BondR) umumnya lebih tinggi (sesuai riset Asih, 2012). Penelitian ini akan menguji posisi SIZ apakah lebih baik sebagai variabel kontrol atau sebagai variabel bebas. Untuk itu, dilakukan dua kali pengujian sebagaimana dimaksud dalam persamaan satu dan dua.

\section{METODA PENELITIAN}

Penelitian ini bersifat kuantitatif dengan populasi seluruh perusahaan penerbit obligasi korporasi yang terdaftar di Bursa Efek Indonesia (BEI) dan tercatat dalam Indonesia Bond Market Directory (IBMD). Sementara itu, sampel penelitian diobservasi menggunakan teknik purposive dengan kriteria obligasi yang berasal dari perusahaan nonkeuangan dan diperingkat oleh PEFINDO selama perioda 2012-2014. Tabel 2 menyajikan tahapan seleksi sampel penelitian dan jumlah data observasi.

Tabel 2. Tahap Seleksi Sampel

\begin{tabular}{clc}
\hline No & \multicolumn{1}{c}{ Perusahaan Penerbit Obligasi } & Jumlah \\
\hline 1 & $\begin{array}{l}\text { Perusahaan BUMN dan Swasta penerbit obligasi } \\
2\end{array}$ & $\begin{array}{l}\text { Perusahaan BUMN dan Swasta penerbit obligasi yang bergerak } \\
\text { di sektor keuangan }\end{array}$ \\
3 & $\begin{array}{l}\text { Perusahaan BUMN dan Swasta penerbit obligasi yang tidak } \\
\text { diperingkat oleh PEFINDO }\end{array}$ & $(41)$ \\
4 & Laporan Keuangan yang dinyatakan dalam USD & $(1)$ \\
\hline & $\begin{array}{l}\text { Sampel Penelitian } \\
\text { Jumlah Obligasi yang diterbitkan (16 perusahaan) }\end{array}$ & $\mathbf{1 6}$ \\
& Jumlah Data Observasi (34 x 3 tahun) & $\mathbf{3 4}$ \\
\hline
\end{tabular}

Variabel terikat (BondR) dalam penelitian ini menggunakan dummy dengan nilai 1 (untuk kelompok high investment: idAAA, idAA) dan 0 (untuk kelompok low investment: $\mathrm{id} \mathrm{A}, \mathrm{idBBB}, \mathrm{idBB}, \mathrm{idB}, \mathrm{idCCC}, \mathrm{idD})$. Identifikasi proses penentuan low dan high investment mengacu pada penghitungan Tabel 1. Pertumbuhan (GRW) dalam riset ini diukur dengan pertumbuhan Total Aset dari tahun ke tahun. Maturitas (MTR) diukur dengan membagi umur obligasi ke dalam dua kelompok dengan sistem binari 0 dan 1 . Batasan umur menggunakan cut of point 5 tahun di mana 1-5 tahun masuk dalam kategori short term, sedangkan lebih dari 5 tahun dikategorikan long term. Untuk mengukur arus kas operasi (OCF), peneliti menggunakan laporan arus kas yang tersaji dalam laporan keuangan perurusahaan. Sementara itu, variabel kontrol berupa ukuran perusahaan (SIZ) diukur menggunakan nilai kapitalisasi pasar, yaitu jumlah lembar saham biasa yang beredar dikalikan dengan harga pasar saham.

Penelitian ini menggunakan regresi logistik dalam menguji hipotesis-hipotesis riset yang dikembangkan melalui dua tahap pengujian. Tahap pertama menguji model riset dengan tidak memasukkan ukuran perusahaan sebagai variabel kontrol (persamaan satu) dan pengujian kedua dengan memasukkan ukuran perusahaan sebagai variabel kontrol (persamaan dua). 


\section{TEMUAN DAN PEMBAHASAN}

\subsection{Kesesuaian Model Riset}

Pembahasan hasil riset diawali dengan menjelaskan kesesuaian (fit) model riset. Output SPSS pada Tabel 4 menunjukkan dua nilai -2LogL yaitu untuk model yang hanya memasukkan konstanta (Step 0) dan yang kedua untuk model dengan konstanta dan variabel bebas (Step 1). Nilai -2LogL untuk model yang pertama sebesar 126.898 (signifikan secara statistik, di mana $126.898>125.458$ untuk chi-square df 101 dengan probabilitas 5\%) sehingga model estimasi belum fit.

Tabel 4. Tabel Iterasi

\begin{tabular}{rcc}
\hline \multirow{2}{*}{ Step } & \multicolumn{2}{c}{-2 Log Likelihood $(-2$ LogL) } \\
\cline { 2 - 3 } & Tanpa SIZ & Dengan SIZ \\
\hline Step 0 & 126.898 & 126.898 \\
Step 1 & 103.671 & 85.586 \\
\hline
\end{tabular}

Nilai -2LogL untuk model kedua sebesar 103.671 (tanpa SIZ) dan 85.586 (dengan SIZ) menunjukan model tersebut tidak signifikan secara statistik di mana 103.671 lebih kecil dari 122.108 (df 98 prob. 0.05) serta 85.585 lebih kecil dari 120.990 (df 97 prob. 0.05). Dengan demikian, pengujian pada menggunakan SIZ menghasilkan model yang fit. Pengujian berikutnya mengaji overall model of fit yang tersaji pada tabel 5 melalui Omnibus Test.

Tabel 5. Omnibus Test

\begin{tabular}{lcc}
\hline \multirow{2}{*}{ Ket. } & \multicolumn{2}{c}{ Omnibus Test } \\
\cline { 2 - 3 } & Tanpa SIZ & Dengan SIZ \\
\hline Chi-Square & 23.227 & 41.312 \\
df & 3 & 4 \\
Sig. & 0.000 & 0.000 \\
\hline
\end{tabular}

Overall model of fit pada regresi logistik dapat dikaji melalui hasil Omnibus test yang menguji apakah model yang dihipotesiskan menggambarkan data input. Hasil Tabel 5 menunjukan bahwa selisih antara iteration history blok 0 dan blok 1 adalah 23.227 dengan $d f 3$ pada pengujian tanpa SIZ, sedangkan pada pengujian dengan SIZ, nilai Omnibus test adalah 41.312 dengan $d f 4$. Kedua angka ini signifikan secara statistik, artinya penambahan variabel independen pada pengujian tanpa menggunakan SIZ dan menggunakan SIZ dapat memberi pengaruh nyata terhadap kesesuaian model ( $f i t$ ). Kondisi yang sama juga diperoleh dari pengujian menggunakan SIZ, di mana nilai Omnibus test signifikan secara statistik pada angka 41.312. Hal ini mengindikasi bahwa penambahan variabel bebas berupa GRW, MTR, dan OCF ke dalam model ternyata memperbaiki model of fit. 
Tabel 6. Kesesuaian Model dan Koefisien Determinasi

\begin{tabular}{lcc}
\hline \multirow{2}{*}{ Keterangan } & \multicolumn{2}{c}{ Hosmer and Lemeshow Test } \\
\cline { 2 - 3 } & Tanpa SIZ & Dengan SIZ \\
\hline Chi-Square & 4.013 & 6.453 \\
df & 8 & 8 \\
Sig. & 0.856 & 0.597 \\
Determinasi (Nagelkerke's R ${ }^{2}$ ) & 0.286 & 0.468 \\
\hline
\end{tabular}

Pengujian lain untuk melihat kesesuaian dilakukan dengan Hosmer and Lemeshow Test (HLT). Nilai HLT pada pengujian tanpa SIZ berada pada nilai statistik sebesar 0.856 dan 0.597 pada pengujian menggunakan SIZ (nilainya lebih besar dari 0.05). Angka tersebut membuktikan tidak ada perbedaan signifikan antara model dengan nilai observasinya sehingga model dapat diterima karena sesuai dengan data observasinya.

Bagian terakhir pada Tabel 6 menjelaskan koefisen determinasi melalui nilai Nagelkerke $\mathrm{R}^{2}$. Pada pengujian tanpa SIZ, variasi variabel independen dalam menjelaskan probabilitas variasi peringkat obligasi sebesar $28,6 \%$, sementara pada pengujian dengan SIZ, variasi variabel independen dalam menjelaskan probabilitas variasi peringkat obligasi sebesar 46,8\%. Intervensi dengan SIZ menunjukan peningkatan yang signifikan pada nilai koefisien tersebut. Secara umum, kedua model model estimasi tersebut cukup baik.

\subsection{Estimasi Parameter dan Pembahasan}

Bagian ini menjelaskan hasil estimasi model riset. Secara umum, ringkasan hasil estimasi disajikan pada tabel 7.

Tabel 7. Pengujian Model Persamaan Satu

\begin{tabular}{lrlcrcr}
\hline \multirow{2}{*}{ Keterangan } & \multicolumn{6}{c}{ Variables In The Equation } \\
\cline { 2 - 7 } & $B$ & S. E. & Wald & $d f$ & Sig. & Exp $(B)$ \\
\hline Growth & -4.414 & 1.947 & 5.138 & 1 & 0.023 & 0.012 \\
Maturity & 0.186 & 0.132 & 2.008 & 1 & 0.156 & 1.205 \\
OCF & 0.000 & 0.000 & 1.246 & 1 & 0.264 & 1.000 \\
Constant & 0.405 & 0.990 & 0.167 & 1 & 0.683 & 1.499 \\
\hline
\end{tabular}

Pengujian pertama tanpa menggunakan SIZ. Pada tersebut, dapat dijelaskan bahwa sebelum SIZ ditambahkan, variabel pertumbuhan perusahaan berpengaruh signifikan pada aras lima persen (probabilitas 0.023) dan nilai log of odds (B) menunjukan pengaruh negatif. Artinya semakin tinggi pertumbuhan perusahaan, maka semakin rendah probabilitas perusahaan yang akan berada pada peringkat high-investment $\left(\mathrm{H}_{1}\right.$ terdukung). Variabel maturitas berada pada probabilitas 0.156 dan nilai log of odds $(B)$ menunjukan pengaruh positif yang tidak signifikan $\left(\mathrm{H}_{2}\right.$ tidak terdukung). Sementara itu, variabel arus kas operasi mengindikasi hal serupa, di mana menunjukan angka probabilitas sebesar 0.264 dengan log of odds $(B)$ bertanda positif dan tidak signifikan $\left(\mathrm{H}_{3}\right.$ tidak terdukung). 
Tabel 8. Pengujian Model Persamaan Dua

\begin{tabular}{lrrrrrr}
\hline \multirow{2}{*}{ Keterangan } & \multicolumn{6}{c}{ Variables In The Equation } \\
\cline { 2 - 7 } & \multicolumn{1}{c}{ S. E. } & Wald & $d f$ & Sig. & Exp $(B)$ \\
\hline Growth & -6.533 & 2.301 & 8.063 & 1 & 0.005 & 0.001 \\
Maturity & -0.081 & 0.171 & 0.227 & 1 & 0.633 & 0.922 \\
OCF & 0.000 & 0.000 & 1.759 & 1 & 0.185 & 1.000 \\
Size & 0.000 & 0.000 & 10.339 & 1 & 0.001 & 1.000 \\
Constant & 0.971 & 1.122 & 0.748 & 1 & 0.387 & 2.639 \\
\hline
\end{tabular}

Pengujian model persamaan dua memasukan SIZ. Hasil pada tabel 8 dapat menunjukan bahwa setelah SIZ ditambahkan, variabel pertumbuhan perusahaan semakin signifikan (pada aras satu persen) dan tetap konsisten dengan tanda negatif. Pertumbuhan perusahaan yang tinggi umumnya diikuti dengan peningkatan leverage sehingga risiko keuangan (financial risk) perusahaan akan meningkat. Mengacu pada konsep trade-off model of capital structure, risiko keuangan yang meningkat berpotensi mengarahkan perusahaan pada financial distress dan risiko kebangkrutan. Dengan demikian, ketika pemeringkatan obligasi dilakukan pada kondisi corporate growth yang tinggi tanpa diikuti pertumbuhan profitabilitas yang stabil (risiko keuangan tinggi) akan dianggap sebagai hal negatif oleh Penilai karena berpotensi mengarahkan perusahaan pada default risk. Riset ini belum memisahkan antara perusahaan yang memiliki leverage tinggi dan rendah (baik pada kondisi profitabilitas stabil maupun fluktuatif), sehingga belum mampu menjelaskan kemungkinan adanya moderating effect dari tingkat leverage dalam menjelaskan pengaruh corporate growth dan bond ratings.

Pengujian persamaan dua juga menunjukkan adanya pengaruh ukuran perusahaan (SIZ). Variabel ini signifikan pada aras satu persen dengan tanda positif. Intervensi SIZ pada persamaan dua tidak mengubah pengaruh MTR dan OFC terhadap BondR sebagaimana dihasilkan pada hasil uji persamaan satu (Tabel 7). Peneliti menduga bahwa variabel SIZ lebih sesuai diposisikan sebagai variabel bebas dalam menguji BondR dan antesedennya. SIZ yang bertanda positif dalam riset ini menunjukan bahwa nilai kapitalisasi pasar yang besar memiliki probabilitas lebih tinggi untuk mendapatkan rating obligasi yang baik (high-investment). Kapitalisasi pasar (SIZ) yang besar berdasar riset ini mengindikasi potensi default risk yang relatif lebih rendah dibandingkan Penerbit dengan nilai SIZ kecil.

\section{KESIMPULAN}

Pada Model satu, hasil penelitian menunjukan bahwa Pertumbuhan Perusahaan (GRW) berpengaruh negatif signifikan terhadap probabiltas perubahan peringkat obligasi (BondR). Sementara itu, Maturitas (MTR) atau umur jatuh tempo obligasi tidak menunjukan pengaruh terhadap probabilitas perubahan peringkat obligasi di BEI. Hasil serupa juga diperoleh pada pengujian variabel Arus Kas Operasi (OCF). 
Pengujian pada Model 2 menunjukan hasil yang berbeda. Model ini memasukan variabel Ukuran Perusahaan (SIZ) dan diperoleh bahwa ukuran perusahaan yang berbeda ternyata dapat memengaruhi probabilitas perubahan peringkat obligasi. Dengan nilai signifikansi pada aras satu persen dan koefisien regresi logistik yang bertanda positif, dapat disimpulkan bahwa kapitalisasi pasar menurut hasil riset ini berbanding searah dengan probabilitas perubahan peringkat obligasi di BEI.

Berdasar kajian ini, beberapa rekomendasi yang dapat disampaikan sebagai berikut. Pertama, Pertumbuhan Perusahaan dan Ukuran Perusahaan yang dilihat dari kapitalisasi pasar dapat digunakan pemodal sebagai salah satu indikator dalam menganalisis obligasi yang potensial sebagai target investasi. Kedua variabel ini juga perlu diperhatikan para penerbit obligasi karena memiliki konsekuensi empiris terhadap hasil pemeringkatan obligasi. Kedua, Pefindo sebagai salah satu lembaga pemeringkat obligasi di Indonesia perlu mengaji lebih dalam mengenai kedua variabel ini sehingga benang merah dari anteseden-anteseden rating obligasi dapat dianalisis secara komprehensif.

Ketiga, penelitian ini hanya menggunakan kategori low dan high investment dalam menganalisis peringkat obligasi sehingga nilai observasi variabel BondR tidak begitu variatif. Penelitian selanjutnya dapat membagi ke dalam beberapa skala ordinal untuk mengaji lebih dalam mengenai anteseden-anteseden rating obligasi tersebut. Selain itu, riset selanjutnya juga dapat mempertimbangkan beberapa variabel lain, seperti potensi perilaku moral hazard penerbit obligasi yang melakukan praktik earning management, reputasi auditor, memperluas sampel penelitian (perioda analisis), serta menganalisis obligasi yang diperingkat oleh lembaga lain seperti Kasnic Credit Rating. Penyempurnaan-penyempurnaan tersebut diharapkan dapat memberi gambaran yang lebih nyata dalam menganalisis bond ratings dan antesedennya di Pasar Modal Indonesia.

\section{DAFTAR PUSTAKA}

Anthony, J. H. \& Ramesh, K. (1992). Association Between Accounting Performance Measures and Stock Prices, Journal of Accounting and Economics, 15, 203-227.

Asih. (2012). Analisis Faktor-Faktor Yang Mempengaruhi Prediksi Peringkat Obligasi Pada Perusahaan Non Keuangan Yang Terdaftar di BEI 2011-2013, JOM Fekon, 3(1), 74-88.

Bodie, Kane, \& Marcus. (2008). Investments ( $7^{\text {th }}$ Ed.). New York: McGraw-Hill Education.

Darmadji, T. \& Hendy, M. F. (2006). Pasar Modal di Indonesia: Pendekatan Tanya Jawab (Ed. 2). Jakarta: Salemba Empat.

Estiyanti, N. M. \& Gerianta W. Y. (2012). Pengaruh Faktor Keuangan dan Non Keuangan Pada Peringkat Obligasi di Bursa Efek Indonesia, Proceeding Simposium Nasional 
Akuntansi XV, AKPM-53. Banjarmasin: Ikatan Akuntansi Indonesia KAPd \& Universitas Lambung Mangkurat.

Febriani, I., Nugraha, H. S. \& Saryadi. (2013). Analisis Faktor-Faktor Yang Memengaruhi Peringkat Obligasi Pada Lembaga Keuangan Bank Yang Terdaftar Di Bursa Efek Indonesia, E-Jurnal Undip, 2(1), 181-188.

Fauziah, Y. (2014). Pengaruh Likuiditas, Leverage, dan Umur Obligasi terhadap Prediksi Peringkat Obligasi, Jurnal Akuntansi, 2(1), 1-24.

Hartono, J. (2016). Teori Portofolio dan Analisis Investasi. Yogyakarta: BPFEYogyakarta.

Mahfudhoh, R. U. (2014). Analisis Faktor-Faktor Yang Mempengaruhi Peringkat Obligasi, E-Jurnal Undip, 1(1), 1-13.

Murhadi, R. W. (2013). Analisis Laporan Keuangan: Proyeksi dan Valuasi Saham. Jakarta: Salemba Empat.

Octavia, R. (2014). Pengaruh Pertumbuhan Perusahaan, Saldo Laba, dan Aliran Kas Operasi Terhadap Peringkat Obligasi. (Skripsi yang dipublikasikan). Padang: Universitas Negeri Padang.

Rahardjo, S. (2004). Panduan Investasi Obligasi. Jakarta: Gramedia Pustaka Utama.

Restuti, M. I. M. D. (2007). Pengaruh Pertumbuhan Perusahaan Terhadap Peringkat dan Yield Obligasi, Jurnal Akuntansi dan Keuangan, 1(3), 235-248.

Ross, A. S., Westerfield, R. W., Jordan, B. D., Lim, J. \& Tan, R. (2015). Pengantar Keuangan Perusahaan (Fundamentals of Corporate Finance). Jakarta: Salemba Empat.

Safitri, A. (2014). Analisis Faktor-Faktor Yang Mempengaruhi Peringkat Obligasi Perusahaan Manufaktur Yang Terdaftar di Bursa Efek Indonesia. (Skripsi yang dipublikasikan). Surabaya: Sekolah Tinggi Ilmu Ekonomi Perbanas.

Sartono, A. (2012). Manajemen Keuangan Teori dan Aplikasi. Yogyakarta: BPFE.

Sirma Nila Sucipta, N. K. \& Rahyuda. H. (2015). Pengaruh Pertumbuhan Perusahaan, Likuiditas, dan Maturity Terhadap Peringkat Obligasi Perusahaan di Bursa Efek Indonesia. E-Jurnal Manajemen Universitas Udayana, 4 (3), 626-642.

Surya, E. I. (2015). Pengaruh Ukuran Perusahaan (Firm Size), Profitabilitas, Likuiditas, Produktivitas, dan Leverage Terhadap Peringkat Obligasi, Jurnal Akuntansi Unesa, 3 (2).

Susanto, A. (2015). Faktor-Faktor Yang Mempengaruhi Peringkat Obligasi Pada Perusahaan Non Keuangan Tahun 2011-2013. (Skripsi yang dipublikasikan), Semarang: Universitas Negeri Semarang. 
Wijayanti, I. (2014). Faktor-Faktor Yang Mempengaruhi Peringkat Obligasi, Jurnal Ilmu \& Riset Akuntansi. 3 (3), 1-15.

Yuniati, D. (2012). Analisis Hubungan Struktur Kepemilkan dan Ukuran Perusahaan dengan Peringkat Obligasi. (Skripsi yang dipublikasikan) Jakarta: FE Universitas Indonesia. 